\title{
Pre- and Post-Weaning Piglet Performance, Sow Food Intake and Change in Backfat Thickness in a Group-Housing System for Lactating Sows
}

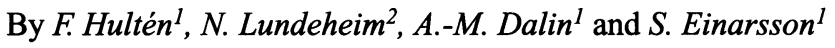 \\ ${ }^{1}$ Department of Obstetrics and Gynaecology, ${ }^{2}$ Department of Animal Breeding and Genetics, Swedish Univer- \\ sity of Agricultural Sciences, Uppsala, Sweden.
}

\begin{abstract}
Hultén, F., N. Lundeheim, A.-M. Dalin and S. Einarsson: Pre- and post-weaning piglet performance, sow food intake and change in backfat thickness in a grouphousing system for lactating sows. Acta vet. scand. 1997, 38, 119-133. - Four farms that group-housed sows from about 2 weeks of lactation until weaning (G-farms) and 3 farms, used as controls, that kept the sows individually penned throughout the 5 to 6week-long lactation period (C-farms) were compared in terms of pre- and post-weaning piglet growth rate and mortality, sow food intake and change in backfat thickness. Piglets from $169 \mathrm{G}$-farm sows and $136 \mathrm{C}$-farm sows were individually weighed at the time of grouping and weaning. In addition, some of the piglets were weighed 2 weeks post weaning. Piglet mortality was recorded during the pre- and post- weaning periods. Sow backfat thickness was measured at the time of grouping (at a corresponding time in the $\mathrm{C}$-farms) and weaning, and sow food consumption was determined during the grouphousing period. Piglet weight, growth rate and within-litter variation in growth rate did not differ significantly between the two groups during the group-housing and postweaning periods. However, the pre- weaning growth rate varied considerably between farms. For multiparous sows during the group-housing period, piglet mortality was higher $(p=0.002)$ in the G-farm group $(6.5 \%)$ than in the C-farm group $(1.4 \%)$. However, for primiparous sows the corresponding piglet mortality was similar $(p=0.21)$ in the two groups. Significant between-batch variation in mortality during the group-housing period was noted within the G-farms but not within the C-farms. At the time of weaning, backfat thickness tended $(p=0.09)$ to be higher in the G-farm group than in the $\mathrm{C}$-farm group. For primiparous sows the decrease in backfat thickness was similar $(p=0.37)$ in the two groups. By contrast, multiparous G-farm sows gained backfat during the group-housing period, whereas multiparous C-farm sows lost some backfat $(p=0.02)$. G-farm sows consumed $23 \%$ more food than C-farm sows during the grouphousing period. These results indicate that productivity is lower in the group-housing system, mainly owing to the poor performance of the older sows.
\end{abstract}

weight; mortality; feeding.

\section{Introduction}

The behavioural repertoire of the swine has remained quite intact through the process of domestication. Like sows of the wild boar, domesticated sows allowed to express their natural behaviour create a social structure that consists of small groups of sows with their offspring (Signoret et al. 1975, Mauget 1981, Stolba \& Wood-Gush 1989). Sows kept under semi-natural conditions nurse their litters for about 15-20 weeks Newberry \& Wood-Gush 1985, Jensen 
\& Recén 1989). Weaning under these conditions is a prolonged process during which family bonds gradually decrease in strength. Piglets become more and more independent of sow milk and they gradually increase their intake of solids (Jensen \& Recén 1989, Jensen \& Stangel 1992, Petersen 1994). Conditions associated with management routines used in commercial pig farming contrast sharply natural conditions. During the short lactation period (3-6 weeks) the sow and her piglets remain in close contact, fairly isolated from other sows, which means that the piglets have ready access to food from their mother. At time of weaning, the sow and piglets are abruptly separated, and the piglet diet is suddenly shifted from mainly milk to solely solids. Moreover, the piglets are often moved to a new environment, and they are sometimes mixed with unknown piglets. The strain these sudden changes cause the piglets is manifested by a stress reaction (Stanton \& Mueller 1976, Worsaae \& Schmidt 1980), behavioural changes (Algers et al. 1990, Metz \& Gonyou 1990), immunodepletion in the early weaned piglet (Blecha et al. 1983 1985, Ekkel et al. 1995), a reduced growth rate one to 2 weeks after weaning (Nimmo et al. 1981, Löfstedt 1986) and diarrhoea, which sometimes causes high mortality (Bäckström 1973, Svendsen 1974).

Based on knowledge of the sows' natural behaviour, group-housing systems for lactating sows have been developed during the last 20 years (Rowlinson et al. 1975, Petchey et al. 1978, Stolba \& Wood-Gush 1980, Håkansson et al. 1990, Bøe 1993), with the purpose of improving welfare and productivity, which includes decreasing disturbances associated with weaning. Group-housing systems seem to promote a gradual decrease in family bonds. Suckling behaviour changes when sows are moved to a group section (Bryant et al. 1983, Bryant \& Rowlinson 1984, Newberry \& Wood-Gush
1985, Braun 1995), and suckling intensity seems to decrease (Hultén et al. 1995b). Some sows wean their piglets and some show oestrus before actual weaning (Rowlinson \& Bryant 1982, Hultén et al. 1995a). These effects are more pronounced among older sows (Hultén et al. $1995 \mathrm{a}, \mathrm{b}$ ). The growth rate of piglets declines temporarily when sows are grouped during lactation (Petchey et al. 1978, Bryant et al. 1983), and a negative relationship between piglet mortality and age at the time of grouping has been noted (Rowlinson \& Bryant 1981, Andersson \& Andréasson 1992). However, previous studies on piglet performance have mainly focused on small groups (3-6 sows), whereas in commercially used group-housing systems the groups can consist of up to 20 sows (Hultén et al. 1995b). Group-housing requires ad libitum feeding to ensure that subordinate sows get enough food (Brouns \& Edwards 1994). It has yet to be determined whether the higher food allowance in the group housing system, as compared to a restricted feeding regime in a conventional housing system, is worth the cost. The objectives of the present study were to:

1. Determine piglet growth rate and mortality during the pre- and post-weaning periods in a commercially used group housing system for lactating sows.

2. Determine sow food intake and change in backfat thickness during the group-housing period.

\section{Materials and methods}

The study was performed at 7 commercial farms located in the south-central parts of Sweden.

In 4 farms the sows farrowed in individual pens and were group-housed from 2-3 weeks after farrowing until weaning (G-farms), whereas in the other 3 farms, used as controls, the sows farrowed batchwise but were housed in individual pens throughout the lactation period (C-farms). 
Table 1. Composition of sow diet used during the group-housing period (kg dry matter-1).

\begin{tabular}{lcc}
\hline & Mean & Range \\
\hline Metabolisable energy, (MJ) & 13.7 & $13.4-13.9$ \\
Crude protein (\%) & 16.1 & $14.8-16.7$ \\
Lysine (\%) & 0.75 & $0.74-0.79$ \\
Methionine (\%) & 0.27 & $0.25-0.29$ \\
Methionine + Cystine (\%) & 0.59 & $0.54-0.61$ \\
Crude fat (\%) & 3.6 & $3.0-4.6$ \\
Crude fibre (\%) & 5.6 & $4.2-7.2$ \\
Ca (\%) & 1.1 & $0.97-1.3$ \\
P(\%) & 0.85 & $0.7-1.0$ \\
\hline
\end{tabular}

The farms have previously been described in detail (Hultén et al. 1995b). All farms had crossbred Swedish YorkshirexSwedish Landrace sows. One G-farm used Duroc boars whereas the others used Hampshire boars, and artificial insemination was used in at least $50 \%$ of the breedings in all farms. The average size of the farrowing pens was $7.2 \mathrm{~m}^{2}$ in both groups. On some farms, sows were crated for 1-2 days at the time of farrowing. Fostering was practised within the same batch of sows in order to even litter size. The piglets' teeth were cut or ground on all farms except on one of the G-farms where teeth were not cut in litters from multiparous sows if the litter size was less than 10. On all farms, piglets were provided iron i.m. within the first 2-3 days of life, and in some farms additional iron was provided i.m or orally 2 weeks later. Furthermore, male piglets were castrated within this period on 2 of the G-farms and 2 of the $\mathrm{C}$-farms, whereas on the other farms castrations were not performed. The group-housing section (G-farms) allowed 6-8 $\mathrm{m}^{2}$ per sow and consisted of isolated buildings with deep straw litter on a concrete floor. In the group-housing section (G-farms) sow food was provided either in dry-food self-feeders, which served 3 sows each, or in troughs at which each sow had $40 \mathrm{~cm}$ of eating space. The lactation period was 5-6 weeks, and boar contact was not allowed during this period. At the time of weaning on all farms, sows were moved to the breeding section while the piglets remained in the nursing section for at least 2 weeks.

On 2 of the G-farms and one of the C-farms liquid feeding was practised (grain, commercial premix and whey), whereas on the other farms the food was given dry. The average daily food ration for dry sows was similar for the 2 groups (25-26 MJ/sow, 120-170 g crude protein/kg dry matter). On all farms, the food ration was gradually increased beginning one to 2 days after farrowing, and the maximum ration was reached between days 10 and 14 of lactation. The average daily food ration was then $88-90$ MJ (150-160 g crude protein $/ \mathrm{kg}$ dry matter) per sow with 10 piglets. In the $\mathrm{C}$-farm group this ration level was maintained throughout lactation, whereas in the G-farm group sows were fed ad libitum during the group-housing period. The composition of the sow diet used during the group-housing period is presented in Table 1 . The piglets were creep fed, in areas off limits to the sows, from the first week of lactation until weaning. Dry piglet food was provided in self feeders or directly on the floor. Prophylactic feed medication or growth promoters were not used on any of the farms. Sporadic cases of diarrhoea, arthritis or other infections among the piglets were individually treated. 


\section{Design}

Some of the sows included in the present study were also part of studies concerning sow health at weaning and ovulation frequency during lactation (Hultén et al. 1995a, b). The present study included 169 group-housed sows divided into 12 batches that each consisted of 12-22 sows ( 3 batches from each farm), and 136 individually housed sows divided into 12 batches that each consisted of 8-21 sows (3-5 batches from each farm). At the time of grouping (at a corresponding time on the $\mathrm{C}$-farms) piglets were provided with an ear tag to allow individual identification. Furthermore, at the times of grouping and weaning piglets were individually weighed (Salter original, which measure to a $200 \mathrm{~g}$ accuracy), and ultrasonic measurements (USK 6, Krautkrämer BmbH \& Co., Hürth, Germany) of sow backfat thickness were made at the last rib, about $8 \mathrm{~cm}$ from the middle of the back. In addition, about 2 weeks after weaning, $59 \mathrm{G}$-farm litters and $39 \mathrm{C}$-farm litters (one batch from each farm) were weighed a third time. Piglet mortality was recorded during the pre- and post-weaning period.

Sow food consumption was recorded during the group-housing period on all $4 \mathrm{G}$-farms and on 2 of the C-farms. On farms where liquid feeding was practised, the total volume of food consumed during this period was recorded batchwise. On one of the G-farms that gave sows dry food, total food consumption was recorded batchwise by using an electronic scale attached to the food mixer. In the other G-farm that provided sows with dry food, total food consumption in the same batch of sows was determined during three $24 \mathrm{~h}$ periods evenly spread out during the group-housing period. Based on these measurements the mean daily food consumption was calculated. On one of the C-farms where feed was given dry, a hand scale was used to record food consumption. The other C-farm on which sows received dry food was excluded from the analysis because food consumption could not be recorded accurately.

\section{Statistical analyses}

Statistical analyses were carried out using SASprocedures (SAS Institute Inc. 1985). All calculations are based on litter means, except those concerning overall piglet mortality during the pre-grouping and group-housing periods. Due to fostering, batch means were used in the analyses of pre-grouping mortality. Similarly, batch means were used in the analyses of overall mortality during the group-housing period, owing to the fact that some piglets lost their ear tags during this period and thus could not be included in calculations of litter means. However, in the analyses of variation in piglet mortality between batches within housing system and analyses of the influence of piglet age, weight and litter size on piglet mortality within each housing system during the group-housing period, litter means were used after exclusion of 3 G-farm batches (50 litters) where ear-tag losses were high (4.3\%-9.2\%). After exclusion of these batches, the mean frequency of ear-tag loss was $0.5 \%$ in the G-farm group and $0.07 \%$ (1 ear-tag) in the C-farm group. Only one ear tag was lost during the post-weaning period.

To avoid inappropriate litter means, litters with less than 5 piglets were excluded from the analyses (7 G-farm litters but no C-farm litters). However, the significance levels obtained excluding the small litters were the same as those obtained using the complete data set. The GLM-procedure (analysis of variation) was used to analyse the different parameters, according to the models presented in Table 2 . When each housing system was analysed separately these models were also used, excluding the effect of housing system in the models. Variation between herds within group was used as error term in the tests of differences between the 2 housing systems, whereas batch within 
Table 2. Models used to analyse the different variables (analysis of variation).

\begin{tabular}{|c|c|c|}
\hline Model No. & Dependent variable & Independent variables \\
\hline \multirow[t]{2}{*}{1.} & $\begin{array}{l}\text { Litter size: } \\
\text { - at birth } \\
\text { - at day of grouping } 1)\end{array}$ & $\begin{array}{l}\text { Housing system ( } 2 \text { ), farm within housing system ( } 4 \text { and } 3) \text {, batch } \\
\text { within farm and housing system ( } 12 \text { and } 12) \text {, age-group ( } 3 \text { classes: } \\
1 \text { st parity, } 2 \text { nd-4th parity and } \geq 5 \text { th parity). }\end{array}$ \\
\hline & $\begin{array}{l}\text { Interval between: } \\
\text { - farrowing and grouping }{ }^{1)} \\
\text { - farrowing and weaning } \\
\text { - grouping }{ }^{1)} \text { and weaning } \\
\text { Parity number }\end{array}$ & (age-group excluded) \\
\hline 2. & Stillborn piglets & $\begin{array}{l}\text { Model No. } 1,+ \text { interaction between housing system and age-group, } \\
\text { and regression on mean litter size. }\end{array}$ \\
\hline 3. & $\begin{array}{l}\text { Piglet growth rate } \\
\text { Sow backfat thickness }\end{array}$ & Model No. $2,+$ regression on mean litter age at time of grouping ${ }^{1)}$ \\
\hline 4. & $\begin{array}{l}\text { Piglet mortality } \\
\text { - pre-grouping period } \\
\text { - } \text { group-housing period }^{1)}\end{array}$ & $\begin{array}{l}\text { Housing system ( } 2 \text { ), farm within housing system ( } 4 \text { and } 3 \text { ), age- } \\
\text { group ( } 3 \text { classes: } 1 \text { st parity, } 2 \text { nd- } 4 \text { th parity and } \geq 5 \text { th parity), interac- } \\
\text { tion between housing system and age-group, regression on mean } \\
\text { litter age at time of grouping }{ }^{1)} \text {, mean No. of piglets born alive (pre- } \\
\text { grouping }{ }^{1)} \text { period), mean litter size at time of grouping }{ }^{1)} \text { (group- } \\
\text { housing period). }\end{array}$ \\
\hline 5. & $\begin{array}{l}\text { Post-weaning piglet } \\
\text { mortality }\end{array}$ & $\begin{array}{l}\text { Housing system ( } 2 \text { ), farm within housing system ( } 4 \text { and } 3) \text {, age } \\
\text { group ( } 3 \text { classes: } 1 \text { st parity, } 2 \text { nd- } 4 \text { th parity and } \geq 5 \text { th parity), interac- } \\
\text { tion between housing system and age-group, regression on mean } \\
\text { litter weight, age and size at time of weaning. }\end{array}$ \\
\hline
\end{tabular}

1) In the C-farm group, measurements were performed at a time corresponding to time of grouping in the G-farms.

2) Due to fostering and ear-tag loss, analyses of differences between housing systems were based on batch means, whereas calculations of differences within each housing system were based on litter means after exclusion of 3 G-farm batches (50 litters) with high ear tag loss.

herd was used as error term in the tests of differences between herds within each housing system. Within each housing system, correlations between growth rate/piglet mortality (batch means) during the group-housing period and mean batch size (12 batches in each housing system) were calculated with the CORR procedure.

P-values, which denote the probability of having observed our data when the null hypothesis is true, are given in the text. P-values $\leq 0.05$ were considered statistically significant.

\section{Results}

There were no significant differences in parity number, litter size or interval from farrowing to grouping or farrowing to weaning between the groups (Table 3). However, parity number tended to be higher in the G-farm group.

\section{Piglet weight and growth rate}

There were no significant differences in piglet weight between the G- and C-farm groups at the time of grouping (at a corresponding time in the $\mathrm{C}$-farm group), at weaning or 2 weeks post 
Table 3. Litter size at birth and at the time of grouping ${ }^{1)}$. Intervals between farrowing and grouping, grouping and weaning, and farrowing and weaning (least square means).

\begin{tabular}{lccc}
\hline & $\begin{array}{c}\text { G-farm } \\
\text { group }\end{array}$ & $\begin{array}{c}\text { C-farm } \\
\text { group }\end{array}$ & P-values \\
\hline No of litters & 169 & 136 & \\
Parity No. & 3.8 & 3.1 & 0.06 \\
Litter size: & & & 0.31 \\
- at birth & 10.6 & 10.9 & 0.61 \\
- at day of grouping & 9.7 & 9.9 & \\
Interval (days): & & & 0.13 \\
Farrowing-grouping & 19.4 & 16.3 & 0.38 \\
Grouping-weaning & 19.7 & 18.5 & 0.78 \\
Farrowing-weaning & 39.2 & 34.8 & \\
\hline
\end{tabular}

1) In the $\mathrm{C}$-farm group, litter size was determined and piglets were weighed at a time corresponding to the time of grouping in the G-farm group.

weaning (Table 4). Similarly, growth rates during the pre- and post-weaning periods did not differ significantly between the the 2 housing systems. In both groups, growth rate seemed to be somewhat lower during the post-weaning period compared with the group-housing period, but there were no differences between groups in the magnitude of the change in growth rate from the pre- to the post-weaning period. The fact that no significant difference in growth rate during the group-housing period was noted between the groups, although the least-square mean growth rate was considerably lower in the G-farm group than in the C-farm group, can partly be explained by the large amounts of variation in growth rate between farms within housing system and between batches within farm and housing system (Fig. 1). Although there seemed to be less variation in the C-farm group, it was significant in both groups. In the G-farm group, growth rate during the grouphousing period was negatively correlated to batch size $(r=-0.67, p=0.02)$. However, batch size was confounded with farm. When the farm with the largest batches (187-215 piglets) was excluded, there was no longer any significant correlation among the remaining batches that ranged in size from 90 to 139 piglets. In the C-farm group, growth rate was not correlated to batch size. In one G-farm batch the farmer noted that during the first week after weaning the piglets' appetite decreased abnormally and the incidence of diarrhoea tended to increase. This caused him to put the piglets on feed medication (Olaquindox) during the second week after weaning. However, piglet growth rate and mortality did not differ significantly between this batch and the other G-farm batches, and for this reason it was included in the calculations. The growth rate during the group-housing period was the same among piglets of primiparous and multiparous G-farm sows, whereas for $\mathrm{C}$-farm animals it was higher among piglets of older sows ( $\geq 5$ th parities) than among piglets of younger ones (Table 5).

Within-litter variation in weight and growth rate did not differ between the 2 housing systems during the pre- and post-weaning period (Table 6). The increase in the variation in piglet weight from the time of grouping to 2 weeks post weaning was about the same for the 2 groups. 


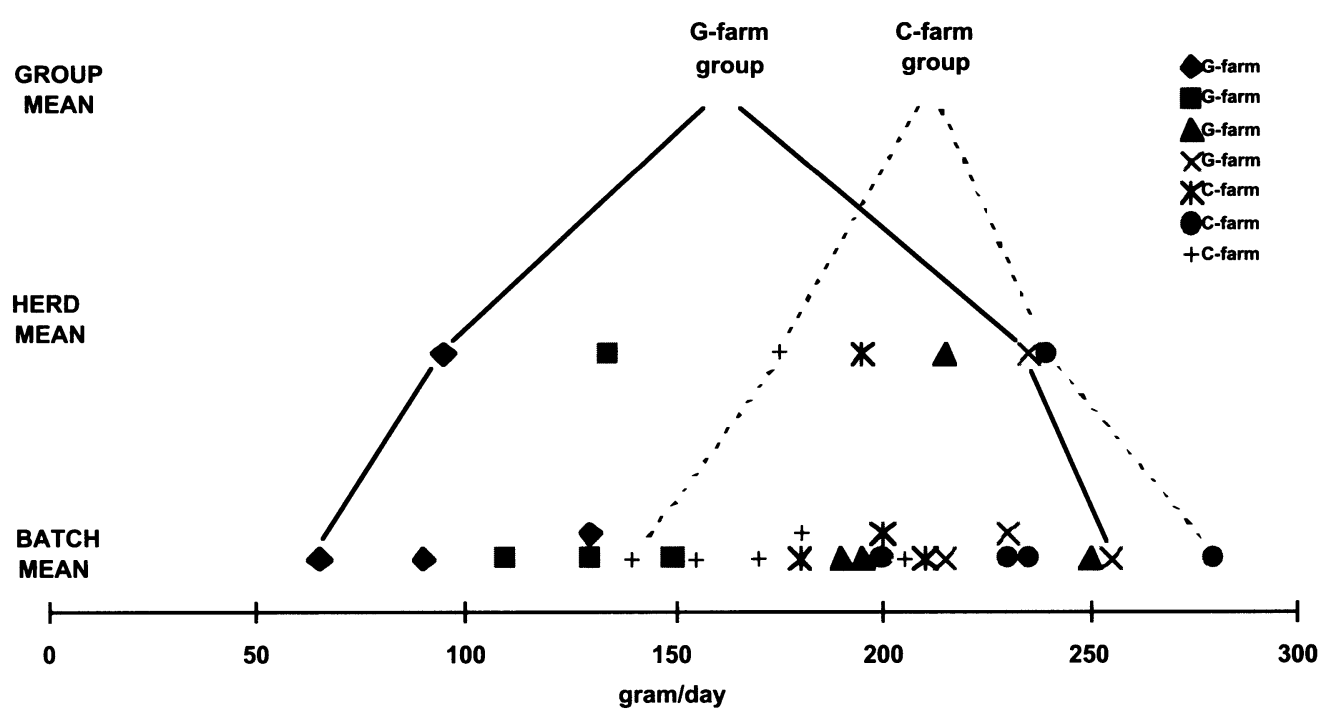

Figure 1. Mean piglet growth rate during the group-housing period (least square means).

\section{Piglet mortality}

Mean percentages of stillborn piglets and piglet mortality during the pre-grouping period did not differ between the 2 housing systems (Table 7). However, during the group-housing period mortality was significantly higher in the G-farm group. Variation in mortality between batches within farm was large $(p=0.01)$ among the G-farms during this period, but was less among C-farms $(p=0.86)$ (Fig. 2). In both groups, higher piglet age and weight at the time of grouping was significantly related $(p<0.03)$ to

Table 4. Piglet weight $(\mathrm{kg})$ at the time of grouping ${ }^{1)}$, at weaning and at 2 weeks after weaning. Growth rate (g/day) during the group-housing and post-weaning period (least square means).

\begin{tabular}{lccc}
\hline & $\begin{array}{c}\text { G-farm } \\
\text { group }\end{array}$ & $\begin{array}{c}\text { C-farm } \\
\text { group }\end{array}$ & P-values \\
\hline No. of sows & 169 & 136 & \\
Weight $(\mathrm{kg}):$ & & & \\
- grouping & 5.3 & 5.6 & 0.50 \\
- weaning & 8.9 & 9.2 & 0.84 \\
- 2 weeks post weaning 2$)$ & 11.0 & 11.0 & 0.92 \\
Growth rate (g/day): & & & \\
- grouping to weaning & 161 & 213 & 0.34 \\
- weaning to 2 weeks post weaning 2$)$ & 150 & 168 & 0.65 \\
- change from pre- to post weaning period & -22 & -34 & 0.79 \\
\hline
\end{tabular}

1) In the C-farm group, piglets were weighed at a time corresponding to the time of grouping in the G-farm group.

2) There were 59 sows in the G-farm group and 39 in the $\mathrm{C}$-farm group. 
Table 5. Piglet growth rate (g/day) during the group housing period ${ }^{1)}$, within parity-number groups (least square means).

\begin{tabular}{lccc}
\hline & $\begin{array}{c}\text { G-farm } \\
\text { group }\end{array}$ & $\begin{array}{c}\text { C-farm } \\
\text { group }\end{array}$ & P-values \\
\hline No. of litters & 169 & 136 & \\
Parity number & & & \\
1 & $157 \mathrm{a}$ & $201 \mathrm{a}$ & 0.70 \\
$2-4$ & $163 \mathrm{a}$ & $215 \mathrm{a}$ & 0.47 \\
$\geq 5$ & $162 \mathrm{a}$ & $222 \mathrm{~b}$ & 0.52 \\
\hline
\end{tabular}

1) In the $\mathrm{C}$-farm group growth rate was determined during a period corresponding to the group-housing period in the G-farm group.

a,b. Values with different superscripts within a row, differ significantly ( $\mathrm{p} \geq 0.05)$.

lower piglet mortality during the group-housing period (the corresponding period in the $\mathrm{C}$-farm group). G-farm piglets that died during the group-housing period weighed $0.9( \pm 1.2) \mathrm{kg}$ less at time of grouping than the ones that survived. The corresponding difference in the $\mathrm{C}$-farm group was $1.0( \pm 1.1) \mathrm{kg}$. Moreover, in the G-farm group, larger litter size at the time of grouping tended $(p=0.06)$ to be related to higher mortality during this period, whereas in the C-farm group litter size did not show any relation to piglet mortality. Among primiparous sows, piglet mortality during the group-housing period did not differ significantly $(\mathrm{p}=0.21)$ between the C-farm group $(2.4 \%)$ and the G-farm group (5.6\%). By contrast, piglet mortality was significantly lower $(\mathrm{p}=0.02)$ among 2-4th parity C-farm sows (1.1\%) compared with $2-4$ th parity G-farm sows $(5.3 \%)$. Similarly, piglet mortality among the older ( $\geq 5$ th parities) G-farm sows was significantly $(p=0.02)$ higher $(8.6 \%)$ compared with that among the older $\mathrm{C}$-farm sows $(1.2 \%)$. There was no correlation between batch size and piglet mortality during the group-housing period in either of the housing systems. During the post-weaning period, mortality was almost equal and quite low in the 2 housing systems (Table 7).

\section{Sow backfat thickness}

Backfat thickness at the time of grouping was about the same $(p=0.49)$ in the G-farm group $(12.8 \mathrm{~mm})$ and the C-farm group (12.4 mm). At time of weaning, $G$-farm sows tended $(p=0.09)$ to have a higher backfat thickness $(14.0 \mathrm{~mm})$ than C-farm sows $(11.4 \mathrm{~mm})$. During the group-housing period, backfat loss occurred among both primiparous G-farm sows $(-0.3$ $\mathrm{mm}$ ) as well as among primiparous C-farm sows $(-1.7 \mathrm{~mm})$, and there were no significant differences between the 2 housing systems $(p=0.37)$. Multiparous $C$-farm sows also lost some backfat $(-0.8 \mathrm{~mm})$ during this period, whereas multiparous G-farm sows gained backfat $(+1.8 \mathrm{~mm})$ during the group-housing period. The change in backfat thickness differed significantly between the multiparous G- and C-farm sows $(p=0.02)$.

\section{Sow food consumption}

Since some farms practised liquid feeding while sows received dry food at others, calculations of food consumption were based on $\mathrm{kg}$ dry matter. During the group-housing period G-farm sows consumed an average of $7.9 \mathrm{~kg}$ (farm range 7.1-8.5 kg) dry matter/day (108 $\mathrm{MJ} /$ day), whereas C-farm sows consumed 6.4 $\mathrm{kg}$ (farm range $=6.3-6.4 \mathrm{~kg})$ dry matter $/$ day $(88$ 
Table 6. Within-litter variation (s.d.) in piglet weight at the time of grouping ${ }^{1)}$, at weaning, and at 2 weeks after weaning. Within-litter variation (s.d.) in growth rate during the group-housing and post-weaning period (least square means).

\begin{tabular}{lccc}
\hline & $\begin{array}{c}\text { G-farm } \\
\text { group }\end{array}$ & $\begin{array}{c}\text { C-farm } \\
\text { group }\end{array}$ & P-values \\
\hline No. of sows & 169 & 136 & \\
Weight $(\mathrm{kg}):$ & & & \\
- grouping & 1.0 & 1.0 & 0.63 \\
- weaning & 1.8 & 1.7 & 0.94 \\
- 2 weeks post & 2.3 & 2.1 & 0.45 \\
$\quad$ weaning) & & & \\
Growth rate (g/day): & 60 & 59 & 0.34 \\
- grouping to weaning & 90 & 66 & 0.13 \\
- - weaning $\rightarrow$ 2weeks post & & & \\
weaning & & & \\
\hline
\end{tabular}

1) In the $\mathrm{C}$-farm group, piglets were weighed at a time corresponding to the time of grouping in the G-farm group.

2) There were 59 sows in the G-farm group and 39 in the C-farm group.

$\mathrm{MJ} /$ day) during the corresponding period. Hence, G-farm sows consumed $23 \%$ more food than C-farm sows during this period.

\section{Discussion}

In the present study, piglet weights and growth rate did not differ between the group-housing system and the conventional housing system. In a previous study on the same type of grouphousing system, growth rate decreased significantly after grouping (Braun 1995). Furthermore, litter weight and litter weight gain during the first week after grouping were lower among small sow groups (3-6 sows) than among conventionally housed sows (Petchey et al. 1978, Bryant et al. 1983). In some studies these differences remained until weaning (Petchey et al. 1978), whereas in others weaning weights were the same in the 2 housing systems (Bryant et al. 1983). The fact that group-housing causes a decrease in sow-piglet interactions and changes in suckling behaviour indicating lowered milk consumption (Bryant et al. 1983, Newberry \& Wood-Gush 1985; Stolba et al. 1990, Hultén et al. 1995a, b) implies that impaired growth among group-housed piglets could be expected. However, creep food intake seems to be higher among group-housed piglets than among conventionally housed ones (Rantzer et al. 1993), and a high intake of solids might compensate for a reduced milk intake. Nevertheless, freeranging piglets do not start to graze before 4 weeks of age (Petersen 1994), and conventionally housed piglets consume very small amounts of food during the first 2 to 3 weeks of lactation (Metz \& Gonyou 1990, Pajor et al. 1991). Thus, a growth lag might occur shortly after grouping owing to the inability of young pigs to compensate for a decrease in milk intake by increasing their intake of solids. At 2-3 weeks of age, creep food intake starts to increase rapidly (Barnett et al. 1989, Pajor et al. 1991, Appelby et al. 1992), and during late lactation, piglets that occupy low-productive teats seem to be able to compensate by increasing 
Table 7. Percentages of stillborn piglets and piglet mortality during the intervals from farrowing to grouping 1 , grouping to weaning, and weaning to 2 weeks post weaning (least square means).

\begin{tabular}{lccl}
\hline & $\begin{array}{c}\text { G-farm } \\
\text { group }\end{array}$ & $\begin{array}{c}\text { C-farm } \\
\text { group }\end{array}$ & p-values \\
\hline No. of litters & 169 & 136 & \\
Stillborn piglets (\%) & 7.4 & 6.4 & 0.19 \\
$\begin{array}{l}\text { Mortality (\%) } \\
\text { farrowing } \rightarrow \text { grouping }\end{array}$ & 9.6 & & \\
- grouping $\rightarrow$ weaning & 6.5 & 9.6 & 0.97 \\
- weaning $\rightarrow$ 2weeks & 1.9 & 1.4 & 0.002 \\
post weaning & & 0.6 & 0.19 \\
\hline
\end{tabular}

1) In the $\mathrm{C}$-farm group piglet mortality was determined during a period corresponding to the group-housing period in the $\mathrm{G}-$ farm group.

2) There were 59 sows in the G-farm group and 39 in the C-farm group.

their creep food intake (Algers et al. 1990). These observations could explain why, as in the present study, weaning weights can be the same among group-housed and conventionally housed piglets. In the present study pre-weaning growth rate varied considerably between farms within the same housing system, although the farms had been selected to resemble each other concerning several parameters (Hultén et al. 1995b). This result emphasises that under commercial conditions unspecified herd factors can strongly influence the results obtained using a specific housing system. The negative correlation between growth rate and batch size should be interpreted cautiously because farm and batch size were confounded, and the sample size was small. Nevertheless, cross-suckling, which could be interpreted as a sub-optimal type of suckling behaviour, is more prevalent in large batches than in small ones (Andersson \& Andréasson 1992, Wülbers-Mindermann 1992, Braun 1995). Thus, in the present study, a high cross-suckling frequency could explain why growth rate was lower in large batches. Previous studies indicate that the reduction in sow-piglet interactions among group-housed sows is positively related to par- ity number (Hultén et al. 1995a, b). However, the present study shows that the piglets of older group-housed sows are able to compensate to the degree that they can grow as fast as the younger sows' piglets. Nevertheless, in the conventional housing system older sows' piglets grew even better than the piglets of younger sows.

In the present study, within-litter variation in growth rate and weaning weight did not differ between housing systems. These results are in accordance with some reports (Petchey et al. 1978), whereas others reported even smaller variation among group-housed sows (Schwartz \& Klement 1992). A reduced growth rate among heavy piglets and an improved nutritional situation among underweight piglets after grouping have previously been noted (Braun 1995) which, together, could partly explain why variation remains limited. In addition, a larger loss of underweight piglets in the group-housing system, as noted in the present study, could also reduce the variation.

Growth rate seemed to decrease in both groups after weaning, and post-weaning growth rate was the same in the 2 housing systems. In conventional housing systems piglets suffer a 


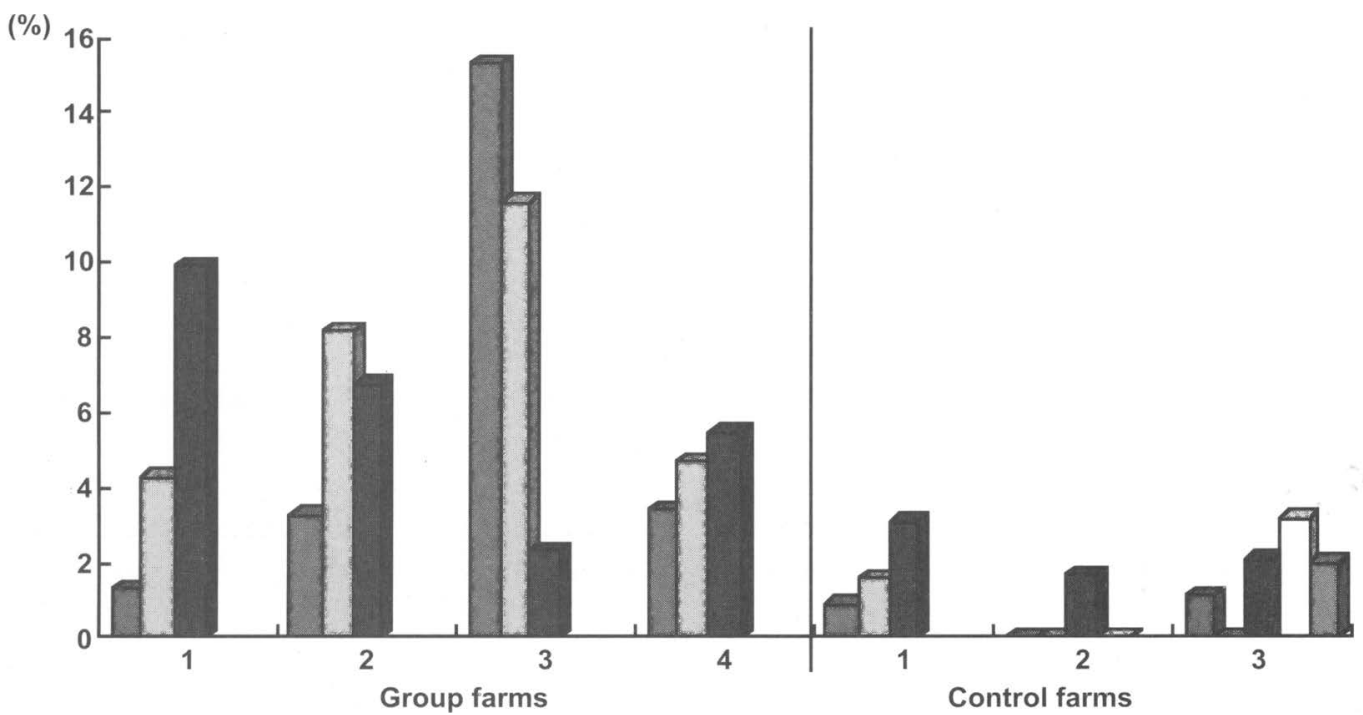

Figure 2. Piglet mortality, within farm and batch, during the group-housing ${ }^{1)}$ period (\%).

1) In the control farms, piglet mortality was determined during a period corresponding to the group-housing period in the group farms.

growth lag the first week after weaning, even if they are creep fed before weaning and remain in the farrowing crate (Nimmo et al. 1981, Funderburke \& Seerley 1990, Pajor et al. 1991). However, growth rate starts to increase again the second week post weaning (Leibbrandt et al. 1975, Nimmo et al. 1981, Pajor et al. 1991). In a previous study where a conventional housing system was compared with a group-housing system in which the sows were able to leave the piglets during the lactation period, a decrease in growth rate after weaning was noted in both systems but growth rate tended to be higher in the group system during the first 2 weeks post weaning (Rantzer et al. 1993). However, in that study, mean growth rate between weaning and 4 weeks after weaning was the same in the 2 housing systems. Moreover, a decrease in growth rate during the first week after weaning was noted among most piglets in a group-housing system identical to the one evaluated in the present study (Braun 1995). Thus, group-housing during lactation does not seem to be an ef- fective way to overcome the negative effects on piglet growth seen after weaning in conventional housing systems. The fact that feed medication had to be used during the post-weaning period in one of the G-farms in the present study further supports this conclusion.

Piglet mortality during the group-housing period was significantly higher in the group-housing system than it was in the corresponding time interval in the conventional housing system. According to calculations based on results from previous studies of small sow groups (3-6 sows) kept in the same type of group-housing system, mean piglet mortality was $6.5 \%$ (range 2.1\%-12.6\%) during the group-housing period (Petchey et al. 1978, Petchey \& Jolly 1979, Rowlinson \& Bryant 1981, 1982, Bryant et al. 1983, Andersson \& Andréasson 1992), which is in accordance with the results from the present study. In addition, as was the case here, piglet mortality was found to be low during late lactation in conventional housing systems in previous studies (Dyck \& Swierstra 1987, 
Sterning et al. 1990, Sterning \& Lundeheim 1995). In the present study, higher age at the time of grouping was related to lower piglet mortality, which is in accordance with previous reports (Rowlinson \& Bryant 1981, Andersson \& Andréasson 1992). That piglet mortality was not correlated to batch size is in agreement with previous studies showing large differences in mortality among small, equally sized sow groups (Petchey et al. 1978, Petchey \& Jolly 1979, Rowlinson \& Bryant 1981, 1982, Bryant et al. 1983). Piglet mortality was higher among multiparous, group-housed sows than among individually penned, multiparous sows, which indicates, in accordance with previous reports (Hultén et al. 1995a, b), that sow-piglet interactions and the degree that the sow cares for her offspring are lower among multiparous grouphoused sows than among primiparous grouphoused sows and conventionally housed sows. In the present study cause of death was not determined. Previous studies have shown that there is a high incidence of overlaying/crushing, especially during the first week after grouping (Andersson \& Andréasson 1992). The marked variation in piglet mortality between batches within the G-farms remains largely unexplained, but factors specific to the grouphousing system, such as the social interactions and establishment of a dominance order among the sows (Meese \& Ewbank 1973, Jensen \& Wood-Gush 1984), the decrease in sow-piglet interactions (Stolba et al. 1990, Hultén et al. 1995b) and the social disturbances associated with the occurrence of oestrus during lactation (Hultén et al. 1995a) could contribute to this variation. Post-weaning mortality was low and equal in both housing systems. Severe outbreaks of post-weaning diarrhoea, associated with high piglet mortality, occur sporadically in conventional housing systems (Svendsen 1974). Disturbances of this kind were not recorded in any of the 2 housing systems during the study period. Nevertheless, feed medication had to be used in one of the G-farms. Close contact among a large number of piglets during the post-weaning period is disadvantageous from an epidemiological point of view. In addition, it might be more difficult to recognise and medically treat a diseased animal in the grouphousing system.

As could be expected from the different feeding regimes, G-farm sows tended to have a higher backfat thickness at time of weaning. Similarly, previous studies show that group-housed sows fed ad libitum gain weight (Rowlinson \& Bryant 1981, 1982). By contrast, conventionally housed primiparous and multiparous sows normally lose weight and backfat during lactation, although they are fed ad libitum or to the point of satiation (Armstrong et al. 1986, Yang et al. 1989, Neil et al. 1996). The fact that multiparous, but not primiparous, group-housed sows gained weight supports previous observations that the level of sow-piglet interaction seems to be reduced in the former case (Hultén et al. $1995 \mathrm{a}, \mathrm{b}$ ). Sow food consumption was considerably higher among group-housed sows, and the resulting extra costs for the farmer were not compensated for by a better litter performance.

\section{Conclusion}

Piglet mortality in the group-housing system during the group-housing period was higher than it was in the corresponding time period in the conventional housing system. In addition, piglet growth rate did not differ between systems during either the pre- or post-weaning period, although sow feed consumption was considerably higher among group-housed sows. These results indicate that productivity is lower in the group-housing system. 


\section{Acknowledgements}

This work was supported by grants from the Farmer's Research Council for Information and Development and the Swedish University of Agricultural Sciences.

\section{References}

Algers B, Jensen P, Steinwall L: Behaviour and weight changes at weaning and regrouping of pigs in relation to teat quality. Appl. Anim. Behav. Sci. 1990, 26, 143-155.

Andersson C, Andréasson, E: Digivande suggor i små grupper. Dygnsrytm, sociala interaktioner och digivningsbeteende. (Group-housed lactating sows in small groups: diurnal rhythm, social interactions and suckling and nursing behaviour). Swedish University of Agricultural Sciences, Uppsala, Sweden. 1992, 1-56.

Appelby MC, Pajor EA, Fraser D: Individual variation in feeding and growth of piglets: effects of increased access to creep food. Anim Prod. 1992, 55, 147-152.

Armstrong JD, Britt JH, Kraeling RR: Effect of restriction of energy during lactation on body condition, energy metabolism, endocrine changes and reproductive performance in primiparous sows. J. Anim. Sci. 1986, 63, 1915-1925.

Barnett KL, Kornegay ET, Risley CR, Lindemann $M D$, Schurig GG: Characterization of creep feed consumption and its subsequent effects on immune response, scouring index and performance of weanling pigs. J. Anim. Sci. 1989, 67, 26982708.

Blecha F, Pollmann DS, Nichols DA: Weaning pigs at an early age decreases cellular immunity. J. Anim. Sci. 1983, 56, 396-400.

Blecha F, Pollmann D S, Nichols DA: Immunologic reactions of pigs regrouped at or near weaning. American J. Vet. Res. 1985, 46, 1934-1937.

Braun S: Individual variation in behaviour and growth of piglets in a combined system of individual and loose housing in sows. Dissertation, (Masters). Swedish University of Agricultural Sciences, Skara, Sweden. 1995, Rapport 36, 1-72.

Brouns F, Edwards SA: Social rank and feeding behaviour of group-housed sows fed competitively or ad libitum. Appl. Anim. Behav. Sci. 1994, 39 , 225-235.

Bryant MJ, Rowlinson P: Nursing and suckling behaviour of sows and their litters before and after grouping in multi-accommodation pens. Anim. Prod. 1984, 38, 277-282.

Bryant MJ, Rowlinson P, Van Der Steen HAM: A comparison of the nursing and suckling behaviour of group- and individually-housed sows and their litters. Anim. Prod. 1983, 36, 445-451.

Bäckström L: Environment and animal health in piglet production. Acta vet. scand. 1973, Suppl 41, $1-240$.

Bøe K: Maternal behaviour of lactating sows in a loose-housing system. App. Anim. Behav. Sci. 1993, 35, 327-338.

Dyck GW, Swierstra EE: Causes of piglet death from birth to weaning. Can. J. Anim. Sci. 1987, 67, 543-547.

Ekkel ED, van Doorn CEA, Hessing MJC, Tielen MJM: The specific-stress-free housing system has positive effects on productivity, health and welfare of pigs. J. Anim. Sci. 1995, 73, 15441551.

Funderburke DW, Seerley RW: The effects of postweaning stressors on pig weight change, blood, liver and digestive tract characteristics. J. Anim. Sci. 1990, 68, 155-162.

Hultén F, Dalin A-M, Lundeheim $N$, Einarsson S: Ovulation frequency among sows group-housed during late lactation. Anim. Reprod. Sci. 1995a, 39, 223-233.

Hultén $F$, Lundeheim N, Dalin A-M, Einarsson S: A field study on group housing of lactating sows with special reference to sow health at weaning. Acta vet. scand. 1995b, 36, 201-212.

Håkansson J, Einarsson S, Ogle B, Bell A: Högbygrinden - möjliggör en friare hållning av digivande suggor. Lantbrukspraktika 1990, 89106.

Jensen P, Recén B: When to wean - Observations from free-ranging domestic pigs. Appl. Anim. Behav. Sci. 1989, 23, 49-60.

Jensen P, Stangel G: Behaviour of piglets during weaning in a semi-natural enclosure. Appl. Anim. Behav. Sci. 1992, 33, 227-238.

Jensen P, Wood-Gush DGM: Social interactions in a group of free-ranging sows. Appl. Anim. Behav. Sci. 1984, 12, 327-337.

Leibbrandt VD, Ewan RC, Speer VC, Zimmermann $D R$ : Effect of weaning and age at weaning on baby pig performance. J. Anim. Sci. 1975, 40, 1077-1080.

Löfstedt M: Clinical and physiological effects of weaning in pigs with special reference to postweaning growth depression. Dissertation. Swed- 
ish University of Agricultural Sciences, Uppsala, Sweden. 1986, 1-82.

Mauget $R$ : Behavioural and reproductive strategies in wild forms of sus scrofa (European wild boar and feral pigs). Curr. Top. in Vet. Med. Anim. Sci. 1981. Vol. II, 3-13.

Meese GB, Ewbank R: The establishment and nature of the dominance hierarchy in the domesticated pig. Anim. Behav. 1973, 21, 326-334.

Metz JHM, Gonyou HW: Effect of age and housing conditions on the behavioural and haemolytic reaction of piglets to weaning. Appl. Anim. Behav. Sci. 1990, 27, 299-309.

Neil M, Ogle B, Annér K: A two-diet system and ad libitum lactation feeding of the sow. 1 . Sow performance. Anim. Sci. 1996, 62, 337-347.

Newberry RC, Wood-Gush DGM: The suckling behaviour of domestic pigs in a semi-natural environment. Behav. 1985, 95, 11-25.

Nimmo S, Pepper TA, Taylor DJ: Measurement of daily live-weight gain of piglets at weekly intervals in the investigation of poor growth performance. Vet. Rec. 1981, 21, 160-163.

Pajor EA, Fraser D, Kramer, DL: Consumption of solid food by suckling pigs: individual variation and relation to weight gain. Appl. Anim. Behav. Sci. 1991, 32, 139-155.

Petchey AM, Dodsworth TL, English PR: The performance of sows and litters penned individually or grouped in late lactation. Anim. Prod. 1978, 27 , 215-221.

Petchey AM, Jolly GM: Sow service in lactation: an analysis of data from one herd. Anim. Prod. 1979, 29, 183-191.

Petersen V: The development of feeding and investigatory behaviour in free-ranging domestic pigs during their first 18 weeks of life. Appl. Anim. Behav. Sci. 1994, 42, 87-98.

Rantzer D, Weström B, Svendsen J, Samuelsson O: Weaning of pigs in a sow controlled and in a conventional housing system. (Avvänjning av grisar $i$ ett suggstyrt och i ett konventionellt inhysningssystem). Swedish University of Agricultural Sciences. Department of Farm Buildings. 1993. Report 85, 1-102.

Rowlinson P, Boughton HG, Bryant MJ: Mating of sows during lactation: observations from a commercial unit. Anim. Prod. 1975, 21, 233241.

Rowlinson P, Bryant MJ: Lactational oestrus in the sow. 1 . The effect of the interval between farrowing and grouping on the incidence and timing of lactational oestrus in sows. Anim. Prod. 1981, 32, 315-323.

Rowlinson P, Bryant MJ: Lactational oestrus in the sow. 2. The influence of group-housing, boar presence and feeding level upon occurrence of oestrus in lactating sows. Anim. Prod. 1982, 34, 283-290.

Schwarz H-P, Klement G: Neueste Ergebnisse aus der Gruppenhaltung von Sauen. Schweine-Zucht und Schweine-Mast. 1992, 40, (Heft 5) 140142.

Signoret JP, Baldwin D, Fraser D, Hafez ESE: The behaviour of swine. In: The behaviour of domestic animals. Balliere Tindal, London. 1975, 295 329.

Stanton HC, Mueller RL: Sympathoadrenal neurochemistry and early weaning of swine. Amer. J. vet. Res. 1976, 37, 779-782.

SAS Institute Inc.: SAS User's Guide: Statistics. 1985. Version 5 Edition. Cary, N. C. 956 pp.

Sterning $M$, Lundeheim $N$ : Some factors influencing pregnancy rate and subsequent litter size in primiparous sows. Acta vet. scand. 1995, 36, 353365.

Sterning M, Rydhmer L, Eliasson L, Einarsson S, Andersson $K$ : A study on primiparous sows of the ability to show standing oestrus and to ovulate after weaning. Influences of loss of body weight and backfat during lactation and of litter size, litter weight gain and season. Acta vet. scand. 1990, $31,227-236$.

Stolba A, Henderson R, Wechsler B: The influence of different social and physical environments on the incidence of lactational oestrus in sows. Appl. Anim. Behav. Sci. 1990, 27, 269-276.

Stolba A, Wood-Gush DGM: Verhaltensgliederung und Reaktion auf Neureize als ethologische Kriterien zur Beurteilung von Haltungsbedingungen bei Hausschweinen. Aktuelle Arbeiten zur Artgemässen Tierhaltung. 1980, 264, 110-128.

Stolba A, Wood-Gush DGM: The behaviour of pigs in semi-natural environment. Anim. Prod. 1989, 48, 419-425.

Svendsen J: Enteric Escherichia coli diseases in weaned pigs. Nord. Vet. Med. 1974, 26, 226-238.

Worsaae H, Schmidt M: Plasma cortisol and behaviour in early weaned piglets. Acta vet. scand. 1980, 21, 640-657.

Wülbers-Mindermann $M$ : Characteristics of crosssuckling piglets reared in a group housing system. Swedish University of Agricultural Sciences, Skara, Sweden. 1992, 13, 1-77. 
Yang H, Eastham PR, Phillips P, Whittemore CT: Reproductive performance, body weight and body condition of breeding sows with differing body fatness at parturition, differing nutrition during lactation, and differing litter size. Anim. Prod. 1989, 48, 181-201.

\section{Sammanfattning \\ Grupphållning av digivande suggor: En studie av smågrisarnas tillväxt och dödlighet samt suggornas foderkonsumtion och hullutveckling. \\ Undersökningen utfördes i fyra besättningar som grupperade suggorna från två veckor efter grisningen till avvänjningen (G-gruppen) samt $i$ tre besättningar (kontroller) som inhyste suggorna enskilt under hela diperioden (K-gruppen). Samtliga suggor var svensk yorkshire×svensk lantras och diperioden var 5-6 veckor lång. Suggorna $\mathrm{i} \mathrm{K}$-gruppen utfodrades re- striktivt under diperioden medan suggorna i G-grup- pen utfodrades ad libitum under grupphållnings- perioden. Smågrisarna från 169 kullar i G-gruppen och 136 kullar i K-gruppen vägdes individuellt i sam-}

band med grupperingen (motsvarande tidpunkt $i$ K-gruppen) och vid avvänjningen. Dessutom vägdes en del av dessa kullar 2 veckor efter avvänjningen. Smågrisdödligheten registrerades. Suggornas hull uppmättes vid grupperingen och vid avvänjningen, och foderkonsumtionen registrerades under grupphållningsperioden. Smågrisarnas vikt, och tillväxt, skiljde sig ej signifikant mellan de båda inhysningssystemen, vare sig före eller efter avvänjningen. Variationen $i$ tillväxt inom kullen var också lika $i$ båda systemen. Under grupphållningsperioden var smågrisdödligheten ungefär lika stor $(p=0,21)$ hos förstagrisarnas kullar i båda inhysningssystemen, medan de äldre suggornas kullar i G-gruppen visade högre $(6,5 \%)(p=0,002)$ dödlighet jämfört med K-gruppen $(1,4 \%)$. Variationen i tillväxt och dödlighet var mycket stor mellan gårdarna och grupperna inom varje inhysningssystem.

Späcktjockleken minskande i ungefär samma omfattning hos förstagrisarna i båda systemen. De äldre suggorna i K-gruppen minskade också i hull, medan de äldre suggorna i G-gruppen ökade i hull $(p=0.02)$. Suggorna i G-gruppen konsumerade $23 \%$ mer foder jämfört med suggorna i K-gruppen.

(Received August 29, 1996; accepted December 5, 1996).

Reprints may be obtained from: F. Hultén, Department of Obstetrics and Gynaecology, Swedish University of Agricultural Sciences, P.O. Box 70 38, S-75007 Uppsala, Sweden. E-mail: fredrik.hultén@og.slu.se, fax: +46-18674535, tel: $+46-18672173$. 


